\title{
The influence of molasses and yeast culture on the performance of growing bulls on grass silage-based diet
}

\author{
P. Huhtanen ${ }^{1}$ and Kari Hissa ${ }^{2}$ \\ 'Agricultural Research Centre, Institute of Animal Production \\ FIN-31600 Jokioinen, Finland \\ ${ }^{2}$ Suomen Rehu Ltd. \\ PO Box 105, FIN-00241 Helsinki, Finland
}

(Received 16 January 1996; accepted 9 July 1996)

\begin{abstract}
The effects of dietary inclusion of yeast culture (YC) and of gradually increasing proportion of sugar beet molasses $\left[0\left(\mathrm{M}_{0}\right), 100\left(\mathrm{M}_{100}\right)\right.$ and $\left.200\left(\mathrm{M}_{2000}\right) \mathrm{g} \mathrm{kg}^{-1}\right]$ in the concentrate mixture on feed intake, live weight gain and carcass characteristics of growing Ayrshire bulls were examined in a $3 \times 2$ factorial design. Twenty-cight animals with a mean initial liveweight (LW) of $268 \mathrm{~kg}$ were used. Molasses replaced a part of concentrate, which was based on a mixture (1:1) of barley and sugar beet pulp. Grass silage was offered ad libitum and the concentrate supplements at the rate of $100 \mathrm{~g}$ per $\mathrm{LW}^{0.6}$ on air dry basis. YC ( $\left.5 \mathrm{~g} \mathrm{day}^{-1}\right)$ was top-dressed on the concentrate. Feed intake was not affected by the treatments but LW gain decreased lincarly $(P<0.05)$ with increasing rate of molasses $(1.21$, 1.16 and $1.09 \mathrm{~kg} \mathrm{day}^{-1}$; SEM 0.029). As the proportion of molasses increased from 0 to $200 \mathrm{~g} / \mathrm{kg}$ concentrate the efficiency of feed conversion declined (linear effect $P<0.01$ ) from 6.10 to $6.75 \mathrm{~kg} \mathrm{DM}$ $\mathrm{kg}^{-1} \mathrm{LW}$ gain. YC had no significant effect either on feed intake (7.26 vs $7.49 \mathrm{~kg} \mathrm{day}{ }^{-1}$ ) or $\mathrm{LW}$ gain (1.14 vs $\left.1.17 \mathrm{~kg} \mathrm{day}^{-1}\right)$. Yeast interacted with concentrate so that with $\mathrm{M}_{0} \mathrm{LW}$ gain was increased and with $\mathrm{M}_{200}$ decreased by $\mathrm{YC}$. The differences in carcass weight and carcass gain reflected a pattern similar to those in LW gain. Dressing proportion and fat grades were not affected by the treatments but carcass quality grade was better in animals receiving $\mathrm{YC}$.
\end{abstract}

KEY WORDS: growing cattle, yeast culture, molasses, silage

\section{INTRODUCTION}

Yeast cultures (Saccharomyces cerivisiae) have been used as a dietary supplement for ruminants for many years. It has been thought to improve rumen 
function, and therefore, production and feed efficiency. However, the responses in liveweight gain and milk production have been variable (Wallace, 1994). It appears that the effects of the products are dependent on the composition of the basal diet. The greatest responses have been observed with high-concentrate diets (Williams and Newbold, 1990; Carro et al., 1992a). This may be related to the stabilizing effect of yeast culture on rumen fermentation and to a reduction in postprandial concentration of lactic acid (Williams, 1989).

In Finland beef production is based on the utilization of large quantities of grass silage in the diet. Feeding grass silage-based diets is characterized by a high postprandial concentration of ammonia $\mathrm{N}$ in the rumen. Extensive proteolysis and fermentation of water soluble carbohydrates of the grass in the silo leads to unbalanced supply of energy and nitrogen for rumen microbes. Sugar supplements have been used to better match energy and $\mathrm{N}$ supply from silage for rumen microbes (Syrjälä, 1972; Chamberlain et al., 1985). Although sugar supplements were in these studies more efficient than starch supplements in reducing the concentration on ammonia $\mathrm{N}$ in the rumen, production responses to replacement of other carbohydrate sources with sugar-rich supplements have been disappointing in production experiments (e.g. Huhtanen, 1987). This may be associated with an increased production of lactic acid and low postprandial rumen $\mathrm{pH}$ on diets rich in sugars (Khalili and Huhtanen, 1991).

The objective of the present study was to evaluate the efficiency of a yeast culture supplement in growing cattle fed a grass silage-based diet. Another specific objective was to determine whether the adverse postprandial effects of a sugar supplement given as sugar beet molasses can be alleviated by yeast supplementation.

\section{MATERIAL AND METHODS}

Diets

Silage was prepared from a secondary growth timothy (Phleum pratense) sward harvested with a flail-harvester. A formic acid-based additive was applied at the rate of 4 litres $t^{-1}$ of grass at the time of harvesting. The grass was ensiled in a bunker silo. Grass silage was offered ad libitum in amounts of $0.05-0.10$ in excess of previous day's intake. The silage was given once daily and the concentrates twice daily in two equal portions. The ingredients of the concentrate mixtures are shown in Table 1. Of the basal concentrate $\left(\mathrm{M}_{0}\right)$, a mixture of barley and unmolassed sugar beet pulp (1:1) was gradually replaced with beet molasses at the rates of $100\left(\mathrm{M}_{100}\right)$ or $200 \mathrm{~g} \mathrm{~kg}^{-1}\left(\mathrm{M}_{200}\right)$. Each concentrate mixture was given either without $\left(\mathrm{Y}^{-}\right)$or with $(\mathrm{Y}+)$ live yeast culture (Western Yeast Culture 
Cel-Con; Western Yeast Company, U.S.A.) supplementation.Yeast culture (YC) was top-dressed to the concentrate at a rate of $5 \mathrm{~g} \mathrm{day}^{-1}$. The concentrates were given at a rate of $100 \mathrm{~g}$ per $\mathrm{kg}$ liveweight $(\mathrm{LW})^{0.60}$ on fresh weight basis to maintain a constant forage to concentrate ratio in the diet throughout the experiment. Refusals were removed once daily before the afternoon feeding. The bulls had a free access to water.

\section{Animals and design}

Twenty-eight Finnish Ayrshire bulls, with an average liveweight of $268 \mathrm{~kg}$, were divided according to liveweight into five blocks of six ( 3 blocks) or five ( 2 blocks) animals. Within the block the animals were allocated at random to the six experimental treatments in a $3 \times 2$ factorial design (three concentrate supplements without or with yeast culture supplementation). The number of animals for the concentrate treatments were 9-10 and for yeast culture treatments 14 . Animals were held in individual stalls.

\section{Experimental procedures}

Daily silage and concentrate intakes were recorded individually. The liveweights of the animals were recorded before the morning feeding on two consecutive days at the beginning and at the end of the experiment. During the experiment the animals were weighed at 4-week intervals. The treatments were imposed for periods of 140 ( 2 blocks) or 168 days ( 3 blocks). The animals with a heavier initial liveweight remained five $28-\mathrm{d}$ periods in the experiment and those with a lighter initial liveweight six $28-\mathrm{d}$ periods to reach an average LW of $440 \mathrm{~kg}$. Silage was sampled once a week and weekly samples were composited to provide a sample for a 4-week period. Each concentrate was mixed in one batch. The samples were collected during the experiment once a week and composited to provide two samples for each concentrate mixture. At the end of the experiment the animals were slaughtered. Carcass conformation and fat scores were assessed according to Finnish standards. Conformation was described on a 1 to 6 scale ( 6 best) and fat scores from 0 (very lean) to 5 (very fat).

\section{Chemical and statistical analysis}

The chemical analysis of the feed samples and silage fermentation quality were those as described by Jaakkola et al. (1990). Metabolizable energy (ME) contents of the feeds were calculated according to the Ministry of Agriculture, Food and Fisheries (MAFF, 1975). The treatments were arranged factorially and data was subjected to analysis of variance. The model included the effects of block, concentrate, yeast and yeast $x$ concentrate interaction with 18 degrees of freedom 
TABLE 1

Composition of concentrate mixtures, $\mathrm{g} \mathrm{kg}^{-1}$

\begin{tabular}{lccr}
\hline & \multicolumn{3}{c}{ Concentrate } \\
\cline { 2 - 4 } Ingredient & $\mathbf{M}_{0}$ & $\mathbf{M}_{100}$ & $\mathbf{M}_{200}$ \\
\hline Barley & 320.0 & 283.3 & 246.6 \\
Molassed sugar beet pulp & 320.0 & 283.3 & 246.6 \\
Oat hults & 40.0 & 40.0 & 40.0 \\
Wheat middlings & 140.0 & 140.0 & 140.0 \\
Rapeseed meal & 105.0 & 105.0 & 105.0 \\
Molasses & - & 100.0 & 200.0 \\
Dicalcium phosphate & 10.0 & 8.0 & 8.0 \\
Sodium chloride & 3.0 & 3.0 & 3.0 \\
Calcium carbonate & 10.0 & 12.0 & 12.0 \\
Calcium lignosulphonate & 10.0 & 10.0 & 10.0 \\
Meat and bone meal & 25.0 & 25.0 & 25.0 \\
Fat & 15.0 & 15.0 & 15.0 \\
Trace element premix & 1.0 & 1.0 & 1.0 \\
Vitamin premix $^{2}$ & 1.0 & 1.0 & 1.0 \\
\hline
\end{tabular}

contained (mg g.1): Fe 16.6, Mn 28.5, Cu 10.8, Zn 172, I 3.7 and Co 4.6

${ }^{2}$ vitamin $\mathrm{A}\left(14000 \mathrm{IU} \mathrm{g}^{-1}\right)$, vitamin $\mathrm{D}_{3}\left(2000 \mathrm{IU} \mathrm{g}^{-1}\right)$, vitamin $\mathrm{E}\left(11.5 \mathrm{mg} \mathrm{g}^{-1}\right)$, vitamin $\mathrm{C}\left(97.5 \mathrm{mg} \mathrm{g}^{-1}\right)$ and Niasin $\left(89.1 \mathrm{mg} \mathrm{g}^{-1}\right)$

for error. The effects of the type of concentrate supplement were further separated using orthogonal polynomial contrasts into linear and quadratic effects of the rate of molasses inclusion. Because the experiment was not completely balanced, least square (LS) means are presented in the tables. Liveweight gain was calculated either as a difference or using a second degree polynomial regression. Carcass gain was estimated by assuming a dressing proportion of $500 \mathrm{~g} \mathrm{~kg}^{-1}$ in the beginning of the experiment.

\section{RESULTS}

\section{Feed composition}

The quality of the silage was not very good as indicated by the low value of 0.627 for the in vitro organic matter digestibility and relatively high concentrations of ammonia $\mathrm{N}$, butyric acid and other volatile fatty acids. The differences in the composition of concentrates were as expected (Table 2); NDF and starch contents decreased and sugar contents increased with increasing rate of molasses 
TABLE 2

Chemical composition and calculated feeding values of expcrimental fceds

\begin{tabular}{|c|c|c|c|c|}
\hline & \multicolumn{4}{|c|}{ Concentratcs } \\
\hline & Silage ${ }^{\prime}$ & $\mathrm{M}_{0}$ & $\mathbf{M}_{100}$ & $\mathbf{M}_{200}$ \\
\hline Dry matter, $\mathrm{g} \mathrm{kg}^{-1}$ & 236 & 880 & 872 & 868 \\
\hline \multicolumn{5}{|l|}{ In dry matter, $\mathrm{g} \mathrm{kg}^{-1}$} \\
\hline ash & 113 & 81 & 87 & 95 \\
\hline crude protein & 141 & 158 & 155 & 154 \\
\hline ether extract & 54 & 53 & 50 & 48 \\
\hline crude fibre & 303 & 112 & 105 & 97 \\
\hline $\mathrm{NFE}^{2}$ & 389 & 596 & 603 & 606 \\
\hline NDF & 557 & 368 & 335 & 307 \\
\hline ADF & 314 & 133 & 120 & 116 \\
\hline $\mathrm{ADL}$ & 30 & 25 & 24 & 22 \\
\hline cellulose & 284 & 108 & 96 & 96 \\
\hline hemicellulose & 243 & 235 & 215 & 191 \\
\hline starch & - & 229 & 204 & 173 \\
\hline $\mathrm{WSC}^{3}$ & 18 & 77 & 117 & 160 \\
\hline $\mathrm{ME}, \mathrm{MJ} \mathrm{kg}^{-1} \mathrm{DM}$ & 8.90 & 12.19 & 12.20 & 12.20 \\
\hline
\end{tabular}

${ }^{1}$ in silage: $\mathrm{pH} 4.17$; in $\mathrm{DM}\left(\mathrm{g} \mathrm{kg}^{-1}\right)$ : lactic acid 87 , acetic acid 27 , propionic acid 2.8 , butyric acid 7.0 ; in total $\mathrm{N}\left(\mathrm{g} \mathrm{kg}^{-1}\right)$ : ammonia $\mathrm{N} 91$, soluble $\mathrm{N} 517$

${ }^{2}$ nitrogen free extractives

${ }^{3}$ water soluble carbohydrates

inclusion. The starch content calculated as a difference of $\mathrm{OM}-$ (crude protein + ether extract + NDF + WSC) was on average $50 \mathrm{~g} \mathrm{~kg}^{-1}$ higher than the starch content analysed chemically, probably reflecting a high pectin content of sugar beet pulp. There were no differences in crude protein content or in calculated ME values of the concentrates.

\section{Feed intake and $L W$ gain}

No significant differences were observed in silage or total DM intake between the treatments (Table 3). However, the response to YC in daily silage DM intake tended $(\mathbf{P}<0.10)$ to interact with concentrate being $+0.86 \mathrm{~kg} \mathrm{day}^{-1}$ with $\mathbf{M}_{0}$ and $-0.22 \mathrm{~kg} \mathrm{day}^{-1}$ with $\mathrm{M}_{200}$. Similar interactions were also noted for total DM and calculated ME intakes because the amounts of concentrate refusals were negligible. The average proportion of concentrate in the diet was $390 \mathrm{~g} \mathrm{~kg}^{-1}$ on DM basis.

The average LW gain declined from 1.21 to $1.09 \mathrm{~kg} \mathrm{day}^{-1}$ (linear effect $\mathbf{P}<0.05$ ) as the proportion of molasses in the concentrate increased (Table 4). The difference was similar when LW gain was estimated using a regression 


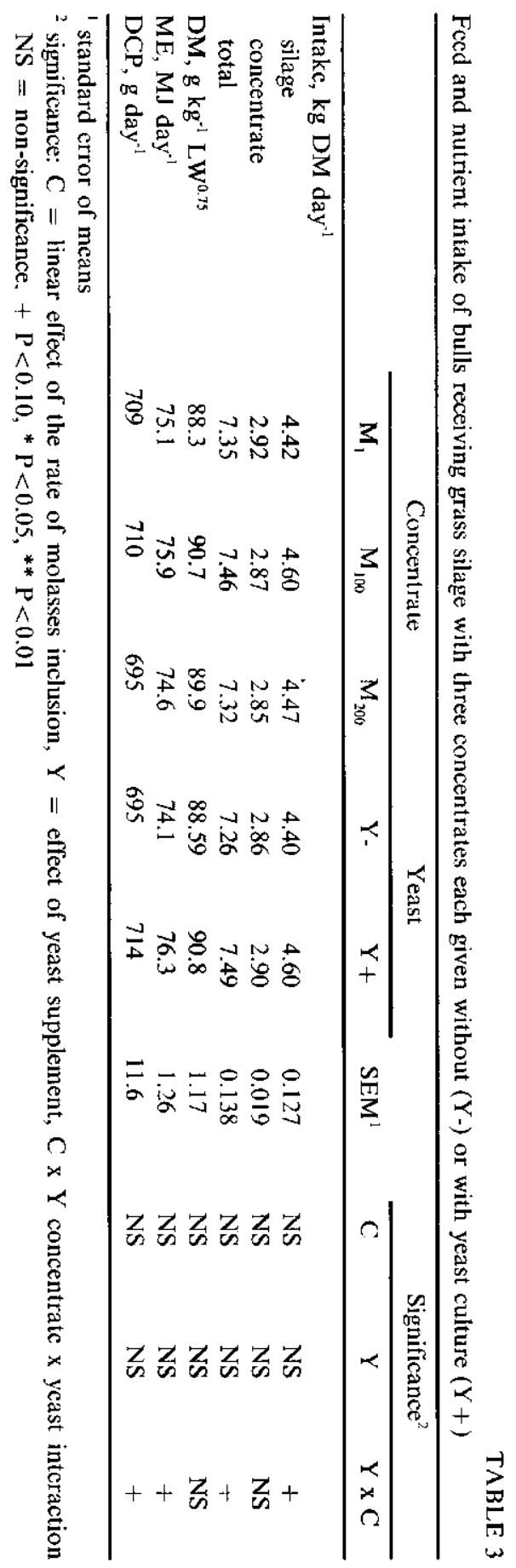




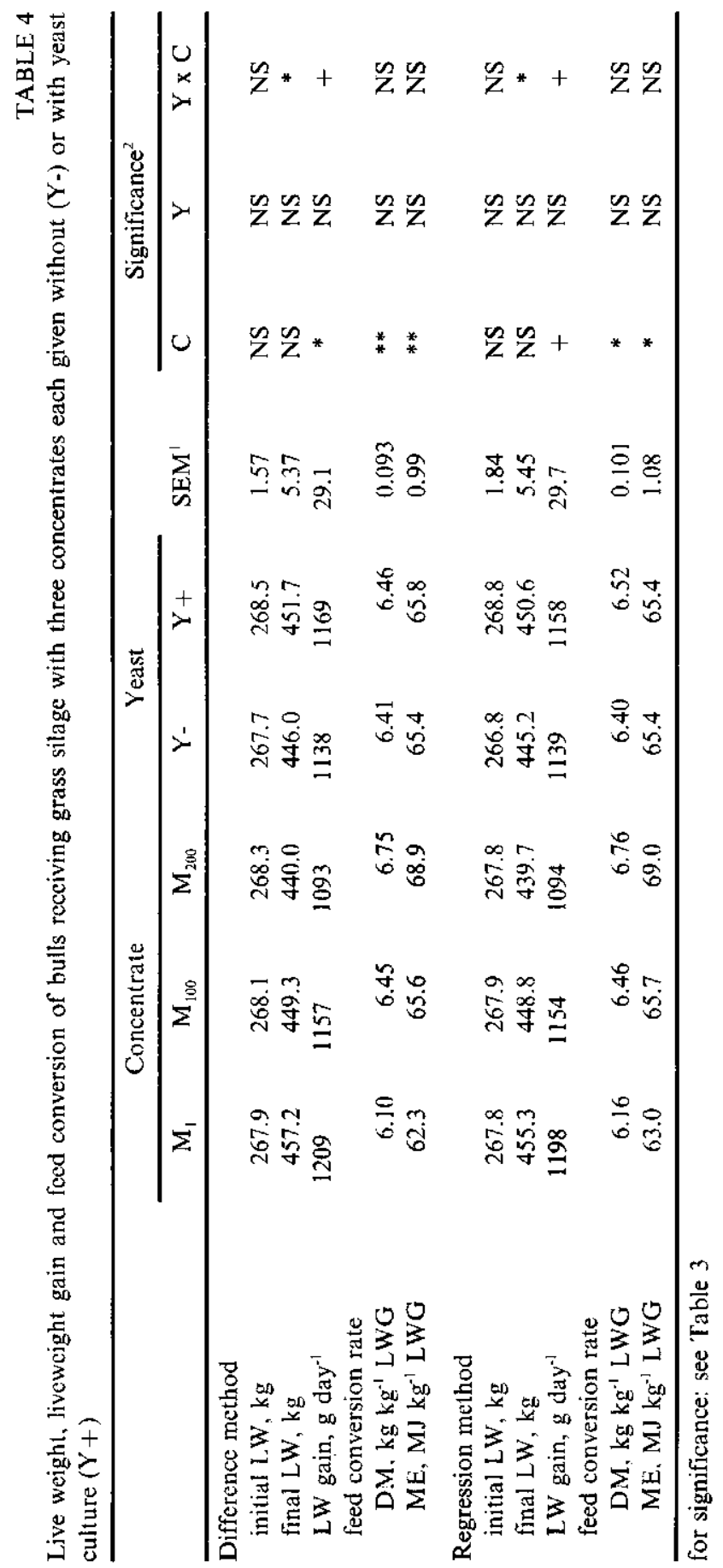




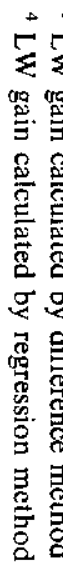

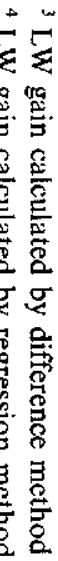

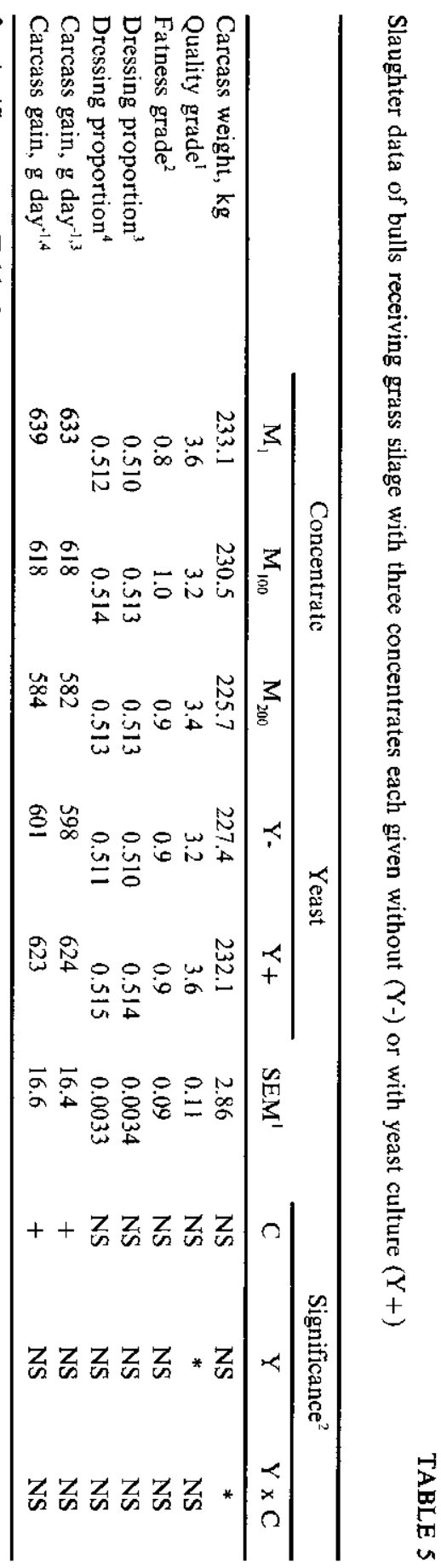


method. YC supplement had no effect on average $\mathbf{L W}$ gain. $\Lambda$ s it was noted for feed intake, the animals receiving $\mathrm{M}_{0}$ were more responsive to $\mathrm{YC}\left(0.18 \mathrm{~kg}\right.$ day $\left.{ }^{-1}\right)$ than those receiving $\mathrm{M}_{200}\left(-0.10 \mathrm{~kg} \mathrm{day}^{-1}\right)$. Feed conversion rate declined $(\mathrm{P}<0.01)$ both in terms of DM and ME used per kg LW gain as the proportion of molasses increased.

\section{Carcass data}

No significant dietary effects on the dressing proportion were observed between the treatments, and the differences in carcass weight reflected those in liveweight (Table 5). Animals receiving yeast had a better $(\mathrm{P}<0.05)$ carcass quality but no significant dietary effects on the fatness grade were observed. Carcass gain declined (linear effect $\mathrm{P}=0.08$ ) with increasing rate of molasses inclusion.

\section{DISCUSSION}

\section{Effect of molasses}

Molasses and other sugar supplements have been used to improve the utilization of silage $\mathrm{N}$ for rumen microbial protein synthesis. There is a variable degree of proteolysis of plant protein during ensilage, and silage $\mathrm{N}$ is rapidly and extensively degraded in the rumen. Feeding grass silage is characterized by high peak values of rumen ammonia $\mathrm{N}$ concentration followed by low concentrations for extensive periods between the meals. In reducing rumen ammonia $\mathrm{N}$ concentration sugar supplements have been more efficient than starch supplements (Syrjälä, 1972; Chamberlain et al., 1985). This has been assumed to be related to the faster energy release from sucrose than from starch (Syrjälä, 1972). Later studies have, however, shown that starch and barley supplementations increase rumen protozoal numbers (Chamberlain et al., 1985) leading to increased recycling of nitrogen in the rumen. Reduced $\mathrm{LW}$ gain of bulls receiving molasses in the present study do not support the idea of synchronization of energy and $\mathrm{N}$ release with easily fermentable carbohydrates, rather the reverse was true.

In agreement with the present results, Drennan et al. (1994) reported reduced LW gain in bulls when cane molasses accounted for $400 \mathrm{~g} \mathrm{~kg}^{-1}$ of concentrate DM and for $180 \mathrm{~g} \mathrm{~kg}^{-1}$ total DM. In a Danish study (Andersen and Fredriksen, 1977), the net energy value for cane molasses was 0.70 of that of barley. Similarly, Huhtanen (1987) reported a negative response in dairy cows given a grass silage-based diet when $2 \mathrm{~kg}$ of molasses was used to replace on DM basis barley or unmolassed sugar beet pulp. 
The reasons for adverse effect of molasses on $\mathrm{LW}$ gain are not clear. The rate of inclusion of molasses in the diet was too small to depress rumen cellulolytic activity. In the studies of Huhtanen $(1987,1988)$ proportions of molasses greater than those used in the present study did not decrease in vivo digestion of cell wall constituents, or the rate or extent of forage DM degradation in the rumen. Similar silage DM intake irrespective of the level of molasses in the diet also suggests that reduced LW gain was not related to differences in silage digestibility or in estimated ME intake. It is possible that the lower LW gain on molasses containing diets was related to reduced supply of amino acids from concentrate. The results of Drennan et al. (1994) indicated a greater reduction in LW gain due to molasses inclusion for low protein than for high protein diets. Molasses contains less rumen undegradable protein than barley and sugar beet pulp. Nitrogen in molasses is mainly in non-protein $\mathrm{N}$ that probably provides less preformed amino acids and peptides for rumen microbes than barley or sugar beet pulp. However, the contribution of molasses to diet DM (40 and $80 \mathrm{~g} \mathrm{~kg}^{-1}$ ) is relatively small to decrease the supply of amino acids markedly. It should also be noted that all supplements contained heat moisture treated rapeseed meal which has sometimes (Aronen et al., 1992) but not always (Huhtanen et al., 1989; Aronen, 1990) improved LW gain in cattle receiving grass silage-based diets.

Because it is not very likely that the origin for reduced LW gain with molasses containing diets lies on inadequate supply of energy and protein yielding nutrients, reduced LW gain must reflect either changes in body composition or in the efficiency of the utilization of ME for growth. Carcass fat scores do not suggest increased fat deposition with molasses in the present study (Table 5), which agrees with results reported by Drennan et al. (1994). Earlier studies (e.g. Lofgreen and Otagaki, 1960) have shown that the net energy (NE) value of molasses depends on its contribution to dietary DM. In cattle the NE value of molasses when it comprised $300-400 \mathrm{~g} \mathrm{~kg}^{-1}$ of dietary DM was only $50 \%$ of that observed at lower levels $\left(100-150 \mathrm{~g} \mathrm{~kg}^{-1}\right)$. In the study of Heineman and Hanks (1977) the calculated energy value of molasses was very sensitive to the level of inclusion. Molasses DM had feeding value of 1.04 and 0.64 relative to barley DM at inclusion rates of 100 and $140 \mathrm{~g} \mathrm{~kg}^{-1}$ of DM, respectively. However, in the present study the amounts of molasses used were below these levels. In the study of Huhtanen and Robertson (1988) a trend towards an increase in heat production with sucrose compared with other carbohydrate sources in the diets of sheep also suggests that the efficiency of energy utilization of diets rich in sucrose may be reduced. In their study, the level of sucrose was much higher than those used in the present study. From this discussion it would appear that despite of rather low rate of inclusion, a lower efficiency of energy utilization is the most likely explanation for reduced performance with molasses containing diets. 


\section{The effect of yeast supplement}

In agreement with other studies in growing cattle (Mutsvangwa et al., 1992; Drennan and Moloney, 1993; Mir and Mir, 1994) YC had only a small effect on LW gain. In studies with cattle offered grass silage, YC supplementation increased LW gain and improved feed conversion efficiency significantly in one of the three trials (Drennan and Moloney, 1993). The effects of YC on digestibility, rumen fermentation pattern and microbial protein synthesis have been small (Huhtanen, 1991: Carro et al., 1992b), and are probably of little biological significance. The published literature shows large variation in response to YC inclusion in the diet, especially in the rumen fermentation pattern but also in ammonia $\mathrm{N}$ concentration, digestibility and ruminal forage degradation. The effects of yeast supplements on the supply of nutrients from the diet are discussed in more detail by Huhtanen (1991), Carro et al. (1992b) and Moloney and Drennan (1994). Recent results of Newbold et al. (1995) suggest that differences exist between strains of $S$. cerevisiae in their ability to modify rumen fermentation which could partly explain the variable responses to YC supplementation. It has also been proposed that increased bacterial viablity is related to partial removal of oxygen entering the rumen (Wallace, 1994). In animals given silage-based diets the amount of oxygen entering the rumen is likely to be smaller than with dried forages which with large population of viable yeast in silage may explain the limited ability of yeast cultures to stimulate rumen fermentation with silage-based diets.

\section{Concentrate $\mathrm{x}$ yeast culture interaction}

An interaction $(\mathrm{P}<0.10)$ between the inclusion rate of molasses and $\mathrm{YC}$ suggested that the effects of YC may depend on the composition of the basal diet. Results from several studies show that the responses to inclusion of YC culture may depend on the composition of the basal diet. Williams et al. (1991) reported that cows given YC increased milk yield when the diet contained $600 \mathrm{~g} \mathrm{~kg}^{\mathrm{l}-}$ of concentrate in the diet but not when the proportion of concentrate was $500 \mathrm{~g} \mathrm{~kg}^{1-1}$. In vitro study by Carro et al. (1992a) indicate that the positive effects of $Y C$ were greatest on the highest proportion of concentrate in the diet. In contrast to these studies, Flachowsky et al. (1993) reported a much greater depressive effect of YC on ruminal DM degradation of forages with a high concentrate than with low concentrate diets. Fiems et al. (1993) found more pronounced effects of YC with maize-silage than with sugar beet pulp. Moloney and Drennan (1994) observed that the effect of $\mathrm{YC}$ on ruminal $\mathrm{N}$ metabolism appeared to be dependant on crude protein content of the basal diet. Rumen ammonia concentration was not affected with a low protein diet but it was reduced with a high protein diet when 
yeast was added. However, these studies do not provide any explanation for the apparent interaction between the composition of concentrate and dietary inclusion of YC in the present study, and therefore it might be worthy to investigate the mechanisms of interactions between diet composition and yeast. In the present study, the decreasing response to $\mathrm{YC}$ with increasing proportion of molasses suggest that a combination of molasses and $\mathrm{YC}$ caused changes in rumen metabolism which had an overall negative impact on animal performance.

In conclusion, the present results confirm the earlier findings that the utilization of grass silage-based diets can not be improved by increasing the sugar content in the supplement. In the present study, molasses caused a decreased LW gain at a lower level of inclusion than observed in previous studies. This was partly related to the adverse effect of $\mathrm{YC}$ with the highest proportion of molasses. Inclusion of $\mathrm{YC}$ had no significant effects on feed intake or $\mathrm{LW}$ gain. The effect of $Y C$ tended to be dependent on the composition of the concentrate. Bccause the responses to dietary inclusion of $\mathrm{YC}$ in nutrient supply and in animal performance appear to depend on the composition of the diet and probably also on the strain of S. cerevisiae used, more research is needed to elucidate conditions in which the use of YC can be economically justified.

\section{REFERENCFS}

Andersen H.R., Fredriksen J.J., 1990. Feeding beet and cane molasses for intensive beef production 497 Beretning fra Statens Husdyrbrugsforsøg

Aronen I., 1990. Barley and rapeseed meal as protein supplements for growing cattle. Acta Agric. Scand. 40, 297-307

Aronen I., Toivonen V., Ketoja E., Öfversten J. 1992., Beef production as influenced by stage of maturity of grass for silage and kevel and type of supplementary concentrate. Agric. Sci. Finl. $2,441-460$

Carro M.D., Lebzicn P., Rohr K., 1992a. Influcnce of ycast culture on the in vitro fermentation (Rusitcc) of dicts containing a variable portions of concentrates. Anim. Feed Sci. Technol. $32,209-220$

Carro M.D., Lebzien P., Rohr K., 1992b. Fifect of yeast culture on rumen fermentation, digestibility and duodenal flow in dairy cows fed a silage based dict. Livest. Prod. Sci. 32, 219-229

Chamberlain D.G., Thomas P.C., Wilson W., Newbold C.J., MacDonald J.C., 1985. The effects of carbohydrate supplements on ruminal concentration of ammonia in animals given grass silage. J. Agric. Sci., Camb. 104, 331-340

Drennan M.J., Moloney A.P., 1993. Effect of yeast culture on of beef cattle fed on grass silage plus barley-based diet. Irish J. Agric. Food Res. 32, 125-132

Drennan M.J., Moloney A.P., Keane M.G., 1994. Fiffects of protein and energy supplements on performance of young bulis offered grass silage. Irish J. Agric. Food Res. 33, 1-10 
Fiems L.O., Cottyn B.G., Dussert L., Vanacker J.M., 1993. Effect of yeast culture on digestibility and rumen fermentation in shecp fed different types of diets. Rep. Nutr. Dev. 33, 43-49

Flachowskiy G., Tiroke K., Matthey M., 1993. Influence of yeast culture (Saccharomyces cerevisiae as Yea-Sacc or Levaferm) on in sacco dry matter degradability and ruminal parameters of variously fed small ruminants. Arch. Anim. Nutr. 42, 159-169

Heincmann W.W., Hanks E.M., 1977. Cane molasses in cattle finishing rations. J. Anim. Sci. 45, 13-17

IIuhtanen P., 1987. The effect of dietary inclusion of barley, unmolassed sugar beet pulp and molasses on milk production, digestibility and digesta passage in dairy cows given silage based diet. J. Agric. Sci. Finl. 59, 101-120

Huhtanen P., 1988. The effects of supplementation of silage diet with barley, unmolassed sugar beet pulp and molasses on organic matter, nitrogen and fibre digestion in the rumen of cattle. Anim. Feed Sci. Technol. 20, 259-278

Huhtanen P., 1991. Effects of yeast culture supplement on digestion of nutrients and rumen fermentation in cattle fed on grass silage barley dict. J. Agric. Sci. Finl. 63, 443-453

Huhtanen P., Robertson S., 1988. The effect of dietary inclusion of starch, sucrose and xylose on the utilization of dietary energy in sheep. Anim. Feed Sci. Techol. 21, 11-21

Huhtanen P., Khalili H., Näsi M., 1989. By-products from integrated starch-ethanol process in the diets of growing cattle. J. Agric. Sci. Finl. 61, 451-462

Jaakkola S., IIuhtanen P., Vanhatalo A. 1990. Fermentation quality of grass silage treated with enzymes or formic acid and nutritive value in growing cattle fed with or without fishmeal. Acta Agric. Scand. 40, 403-414

Khalili H., Huhtanen P., 1991. Sucrose supplements in cattle given grass silage based diet. 1. Digestion of organic matter and nitrogen. Anim Feed Sci. Technol. 33, 247-261

Lofgreen G.P., Otagaki K.K., 1965. Net energy value of fat and molasses for beef heifers with observations made for net energy determination. J. Anim. Sci. 19, 302-403

MAFF (Ministry of Agriculture Food and Fisheries), 1975. Encrgy Allowances and Feeding Systems for Ruminants. Technical Bulletin 33. London

Mir Z., Mir P.S., 1994. Effect of addition of live yeast (Saccharomyces cerevisiae) on growth and carcass quality of steers fed high-forage or high-grain diets and on feed digestibility and in situ degradability. J. Anim. Sci. 72, 537-545

Moloney A.P., Drennan M.J., 1994. The influence of the basal diet on the effects of yeast culture on ruminal fermentation and digestibility in steers. Anim. Feed Sci. Technol. 50, 55-73

Mutcsvangwa T., Edwards I.E., Topps J.H., Paterson G.F.M., 1992. The effect dietary inclusion of ycast culture (Yea-Sacc) on patterns of rumen fermentation, food intake and growth of intensively fed bulls. Anim. Prod. 55, 35-40

Newbold C.J., Wallace R.J., Chen X.B., McIntosh F.M., 1995. Different strains of Saccharomyces cerevisiae differ in their effects on ruminal bacterial numbers in vitro and sheep. J. Anim. Sci. 73, 1811-1818

Syrjälä L., 1972. Tffect of sucrose, starch and cellulose supplements on the utilization of grass silage in ruminants. Ann. Agric. Fenn. 11, 199-276.

Wallace R.J., 1993. Ruminal microbiology, biotechnology, and ruminant nutrition: progress and problcms. J. Anim. Sci. 72, 2992-3003

Williams P.E.V., 1989. The mode of action of yeast culture in ruminant diets: A review of the effects on rumen fermentation pattern. Biotechnology in Feed Industry: T.P. Lyons (Fditor). Proccedings of Altech's Fifth Annual Symposium, pp. 65-84

Williams P.E.V., Newbold C.J, 1990. Rumen probiosis: the effect of novel microorganisms on rumen fermentation and ruminant productivity. In: W. Haresign, D.J.A. Cole (Editors). Recent advances in animal nutrition. Butterworths, London, pp. 211-227 
Williams P.V.E., Tait C.A.G., Innes G.M., Newbold C.J., 1991. Effects of the inclusion of yeast (Saccharomyces cerevisiae plus growth medium) in the diet of dairy cows and forage degradation and fermentation patterns in the rumen of steers. J. Anim. Sci. 69, 3016-3026

\section{STRESZCZENIE}

Wpływ dodatków melasy i kultur drożdży na wyniki opasu buhajków żywionych kiszonką z traw

Doświadczenie opasowe, trwające $168 \mathrm{dni}$, przeprowadzono na 28 rosnących buhajkach Ayrshire o średniej początkowej masie ciała $268 \mathrm{~kg}$ w układzie czynnikowym $3 \times 2$. Buhajki żywiono kiszonką \% traw \% dodatkiem pasz treściwych, uzupełnianych odpowiednio w grupach żywymi kulturami drożdży (YC, $5 \mathrm{~g} /$ dzień) oraz wzrastającą ilością melasy buraczanej $\left[0\left(\mathrm{M}_{0}\right), 100\left(\mathrm{M}_{100}\right)\right.$, i $200\left(\mathbf{M}_{200}\right), \mathrm{g} / \mathrm{kg}$. Mierzono pobranie paszy, przyrost masy ciała i occniano jakość tuszy. Mclasą zastępowano czesść paszy trcściwej, złożoncj ze śruty jęczmiennej i wysłodków buraczanych (1:1). Kiszonkę z traw podawano zwicrzętom do woli, a paszę treściwą w ilości $100 \mathrm{~g} / \mathrm{kg}$ masy ciała $\left(\mathrm{MC}^{0.6}\right)$.

Ilość pobieranej paszy nie rależała od podawanych dodatków melasy i drożdży, natomiast przyrost masy ciała obniżał się liniowo $(\mathrm{P}<0,05)$ wraz ze wzrostem ilości podawanej melasy $(1,21$; 1,16 i $1,09 \mathrm{~kg} /$ dzień; SEM 0,029). W miarę wzrostu udziału melasy od 0 do $200 \mathrm{~g} / \mathrm{kg}$ paszy treściwej, wykorzystanie paszy obniżalo się (efekt liniowy - $\mathrm{P}<0,01$ ) z 6,10 do $6,75 \mathrm{~kg} \mathrm{SM} / \mathrm{kg}$ przyrostu. Dodatek drởdży nie wplynąl na ilość pobieranej paszy $(7,26$ vs $7,49 \mathrm{~kg} / \mathrm{dzień})$ i przyrosty masy ciała (1,14 vs $1,17 \mathrm{~kg} / \mathrm{dzien})$. Stwierdzono interakcję drożdże $\mathrm{x}$ pasza treściwa; pod wpływem dodatku drożdży przyrosty masy ciała w grupie $\mathrm{M}_{0}$, zwiększyły się. a w grupie $\mathbf{M}_{200}$ zmnicjszyły się.

Różnice w masic tuszy i przyrostach masy tuszy miały podobny układ jak różnice w przyrostach żywcj wagi zwierząt. Nie stwierdzono wplywu stosowanych dodatków na wydajność rzeźną i jakość tłuszcru, lec jakość tuszy zwierząt otrzymujących dodatek drożdży była lepsza. 